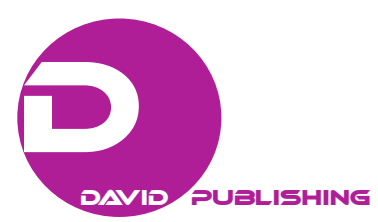

\title{
The Scenario of Lean Product Development in Brazilian
}

$$
\text { Auto-industry* }
$$

\author{
Ana Julia Dal Forno, Fernando Antonio Forcellini \\ Santa Catarina Federal University (UFSC), Santa Catarina, Brazil \\ Henrique Rozenfeld \\ São Paulo University (USP-São Carlos), São Carlos/SP, Brazil \\ Liane Mählmann Kipper, Fernando Augusto Pereira \\ University of Santa Cruz do Sul (UNISC), Santa Cruz do Sul/RS, Brazil
}

\begin{abstract}
The purpose of this paper is to evaluate the impact of lean product development (LPD) in the Brazilian automotive sector. A mailed-questionnaire survey was used to examine 23 questions about LPD principles and practices. The target population for the study was Brazil's largest product development and design companies. The study identified that although the automobile sector is seen as a reference in the adoption of lean practices, there is still potential for improvement by establishing partnership relations with suppliers, and with those on the other points of the chain by identifying what provides value to clients. Set-based concurrent engineering is also a practice that needs to be better developed, as well as the value stream mapping tool to identify waste and activities that add value to the product development process. There has been no previous study of this nature in Brazil that characterizes the sector and highlights its importance in relation to the global scene, providing incentives to international investors. The value of the work is in the results that allow diagnosing the lean development practices that are most used in the automotive sector. Moreover, the survey questions can be applied in other economic sectors and at companies of other sizes. The study contributed to providing a systematic view of the product development process from the perspective of people, processes, and technology, and assists companies and academics manage change.
\end{abstract}

Keywords: auto-industry, lean, product development process, practices

\section{Introduction}

Regardless of the sector in which companies operate, some problems are common including: communication

\footnotetext{
* Acknowledgements: The authors would like to express their appreciation to CAPES (Coordenação de Aperfeiçoamento de Pessoal de Nível Superior) and to the translator Jeffrey Hoff native from New York.

Ana Julia Dal Forno, Ph.D., assistant professor, Department of Engineering, Santa Catarina Federal University (UFSC), Blumenau/SC, Brazil.

Fernando Antonio Forcellini, associate professor, Department of Production Engineering, Santa Catarina Federal University (UFSC), Florianópolis/SC, Brazil.

Henrique Rozenfeld, titular professor, Engineering School, São Paulo University (USP-São Carlos), São Carlos/SP, Brazil.

Liane Mählmann Kipper, titular professor, Systems and Industrial Processes, University of Santa Cruz do Sul (UNISC), Santa Cruz do Sul/RS, Brazil.

Fernando Augusto Pereira, Post Doctoral Researcher, Systems and Industrial Processes, University of Santa Cruz do Sul (UNISC), Santa Cruz do Sul/RS, Brazil.

Correspondence concerning this article should be addressed to Ana Julia Dal Forno, Rua Pomerode, 710 bairro Salto do Norte, Blumenau/SC, Brazil, CEP 89065-300. E-mail: ana.forno@ufsc.br.
} 
barriers; the lack of a product development process (PDP) that is organized in a lean manner; control failures and deliveries that take more time than planned. That is, in most companies there is the poor use of or a waste of knowledge and information. One of the most successful ways of handling this problem is through the lean approach, which works constantly to reduce waste and deliver value to the client. When applied to product development, it has improved processes to make them flow better, without interruptions caused by a variability of tasks, waiting and low reliability of information. The other opportunity for improvement is at the level of product, that is, it is necessary to design something that is easy to manufacture.

The purpose of this article is to describe the diagnostic made after conducting a survey with the largest private companies in terms of income in Brazil's automotive sector. The focus was on identifying the principles and practices of the Lean approach that are being used in the product development process such as value stream mapping (VSM), voice of customer (VOC), early supplier involvement (ESI), standardization, visual management, set-based concurrent engineering (SBCE), virtual simulation, project library, and record lessons learned.

The article is organized in the following manner. The introduction contextualizes the theme and presents the research problem and the objectives. Section 2 groups the concepts of the practices verified in the survey that were the base for the preparation of the questionnaire. It also presents some relevant studies associated to the key-themes - performance indicators, lean approach, and product development process. Details are also presented of the survey methodology, and this article is derived from part of Dal Forno's doctoral thesis (2012) about the automotive industry. The author applied the survey in eight economic sectors of Brazil. The questionnaire was sent to 48 companies in the automotive industry and 22 responded, which is a rate of return of $46 \%$. This amount does not allow generalization, but it is possible to sketch a scenario of this sector and indicate the principles and practices that are being implemented in an isolated and or systematic manner. Section 3 presents the statistical handling conducted with the software Statistica 10.0 and SPSS. The conclusions describe some of the trends for the automotive sector and perspectives for the future. At the end there are the acknowledgements and references used.

\section{Theoretical Principles and Survey Results}

The choice of the automotive sector was justified by the study given that in 2013 Brazil was the world's seventh largest vehicle producer, with this data including cars, light commercial vehicles, trucks, and buses (Table 1). The report, The Brazilian Autoparts Industry Performance 2013, published by Sindipeças (The Brazilian Auto Parts Manufacturers Association), shows that Brazil was in fourth place in sales (Table 2).

Figure 1 shows the Brazilian states from which companies responded to the study. São Paulo (the state with the largest economy in Brazil) had the most participants, with 11 companies. Figure 2 presents the percentage of each responding state. The responding companies include 12 auto parts manufacturers, three automobile manufacturers, three ship, plane or helicopter manufacturers, and four produce buses, tractors, or trucks.

In terms of the positions of the people responding, most are managers (36\%), 32\% are engineers or analysts, followed by coordinators (18\%), as can be seen in Figure 3. 
Table 1

Worldwide Vehicle Production (Major Producing Countries)—2002/2012

\begin{tabular}{llrrr}
\hline Country & & 2002 & 2008 & 2012 \\
\hline 1 & China & 3,287 & 9,299 & 19,272 \\
2 & USA & 12,280 & 8,694 & 10,329 \\
3 & Japan & 10,257 & 11,576 & 9,943 \\
4 & Germany & 5,469 & 6,046 & 5,649 \\
5 & South Korea & 3,148 & 3,827 & 4,558 \\
6 & India & 895 & 2,332 & 4,145 \\
7 & Brazil & 1,792 & 3,216 & 3,343 \\
8 & Mexico & 1,805 & 2,168 & 3,002 \\
9 & Thailand & 585 & 1,394 & 2,483 \\
10 & Canada & 2,629 & 2,082 & 2,464 \\
\hline
\end{tabular}

Source: Sindipeças (2013).

Table 2

Worldwide Vehicle Sales (Major Countries)—2005/2012

\begin{tabular}{llrrr}
\hline & Country & 2005 & 2008 & 2012 \\
\hline 1 & China & 5,758 & 9,381 & 19,306 \\
2 & USA & 17,444 & 13,493 & 14,786 \\
3 & Japan & 5,852 & 5,082 & 5,370 \\
4 & Brazil & 1,715 & 2,820 & 3,802 \\
5 & India & 1,440 & 1,983 & 3,577 \\
6 & Germany & 3,425 & 3,394 \\
7 & Russia & 3,615 & 3,222 & 3,142 \\
8 & United Kingdom & 1,807 & 2,485 & 2,334 \\
9 & France & 2,828 & 2,615 & 2,332 \\
10 & Canada & 2,598 & 1,674 & 1,716 \\
\hline
\end{tabular}

Source: Sindipeças (2013).

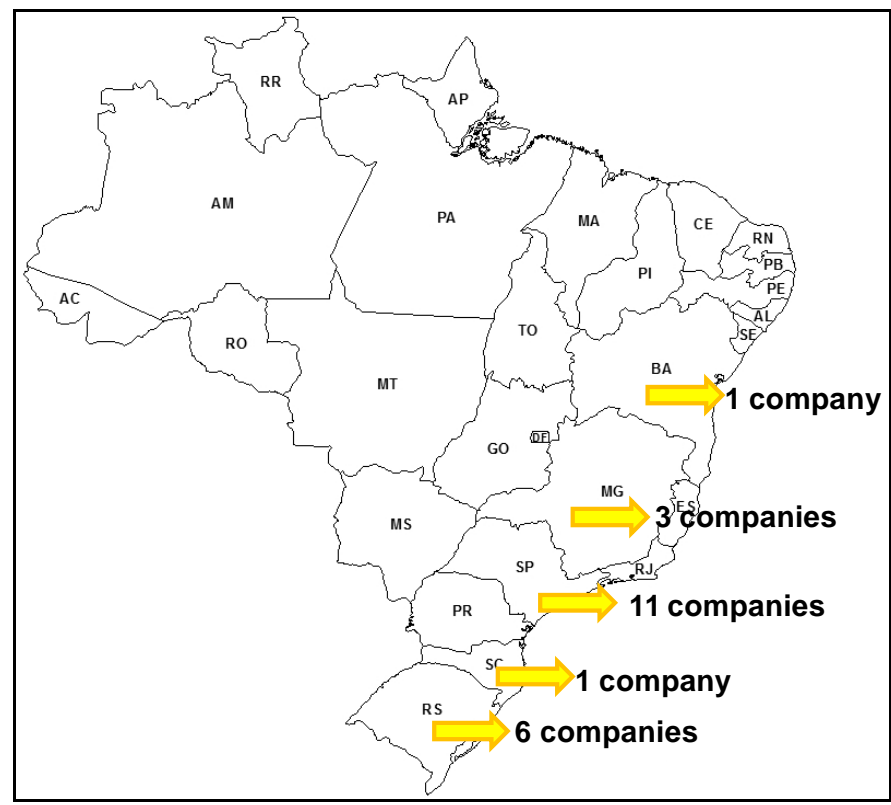

Figure 1. Location of the companies that responded to the study. 


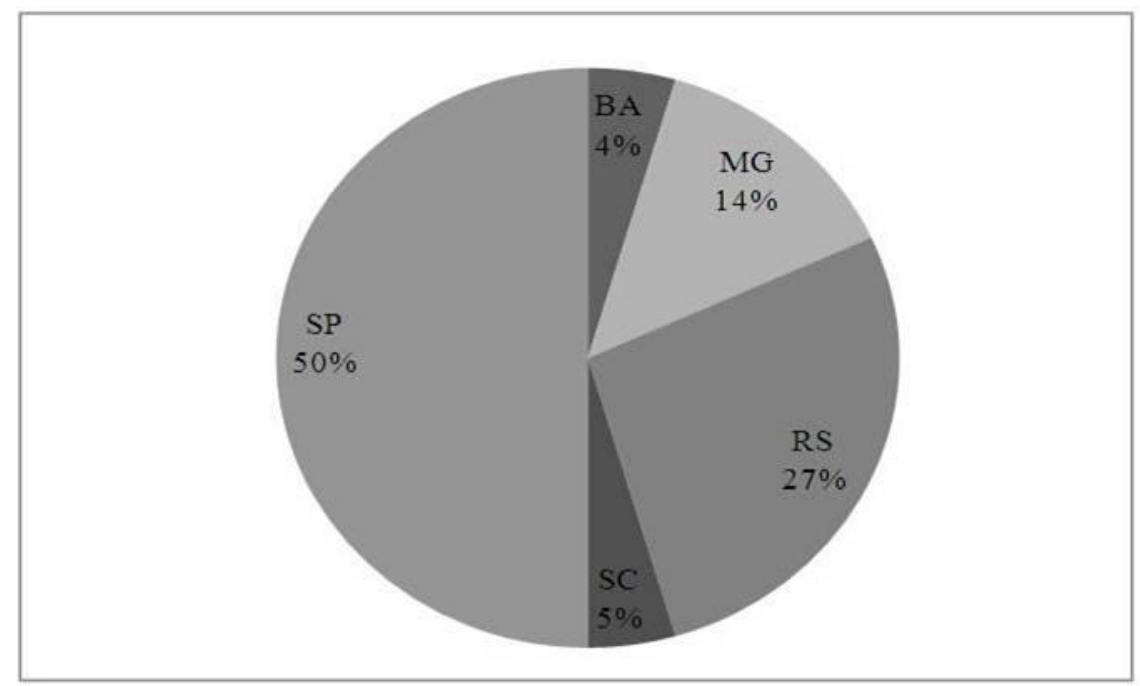

Figure 2. Brazilian states that responded to the automotive industry survey.

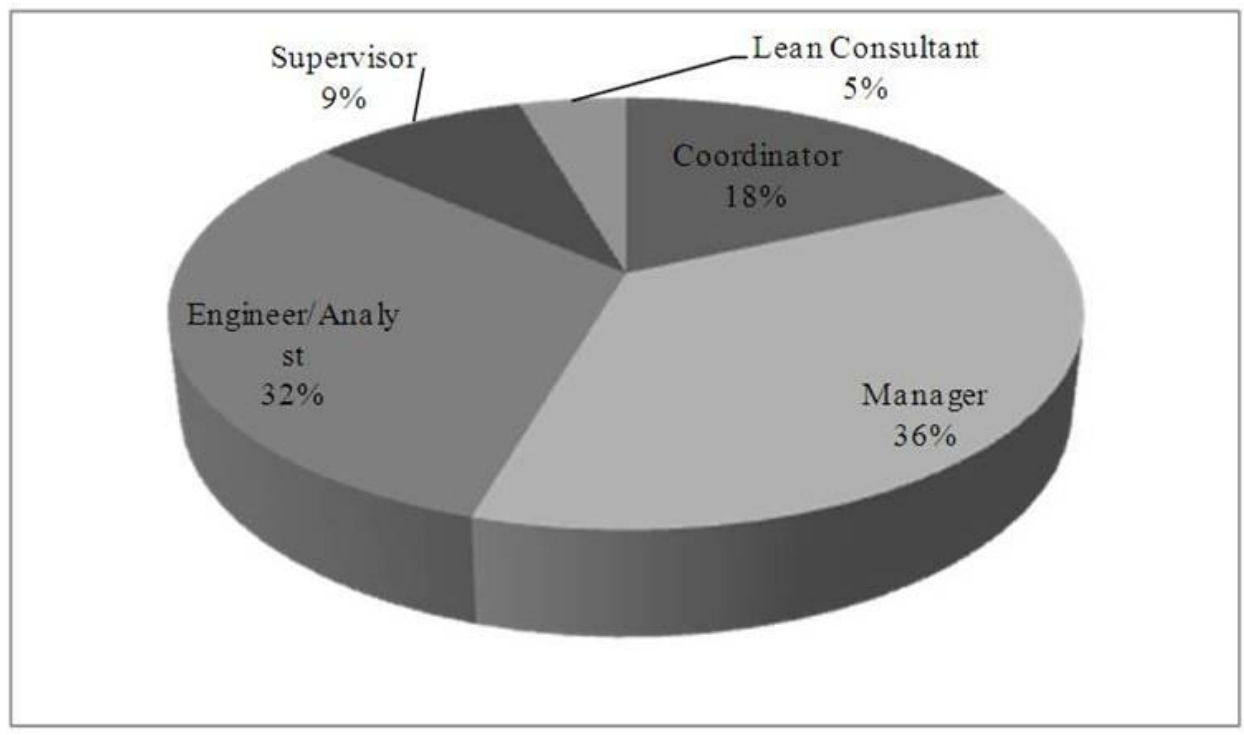

Figure 3. Positions of the respondents.

In relation to the types of projects, Morgan and Liker (2006) used the classifications of radical or breakthrough projects; platform or next generation projects; and incremental or derived projects. In the case of Brazil, there is a fourth category called a follow-source project, which are those that come from the head office or from clients and that are suitable to the local reality. Below is a description of each one of these types of projects, from the most to least complex:

- radical projects (breakthrough) - significant changes occur when a new category or family of products is developed that requires new technologies or materials and in most cases an innovative manufacturing process;

- platform or next-generation projects - significant alterations are involved, but without the use of new technologies or materials, they provide a new system of solutions for clients and have a common structure among the various models in a family;

- incremental or derived projects - the modifications are small and are focused on cost reduction, for example, with incremental innovations in products and processes; 
- follow-source projects - these come from other units of the group, a client or contracted technology, they do not require significant change although the local plant adapts them to local conditions, involving the validation of the process, equipment, tools, production of the pilot lot and the initiation of production.

The survey used two questions to verify these issues. One of them found that $77 \%$ of the products are developed in Brazil and 23\% come from abroad. Figure 4 shows the types of projects of the responding companies, recognizing that more than one option was indicated by the respondents. It is seen that the most common projects were of the radical (38\%) and incremental (34\%) variety.

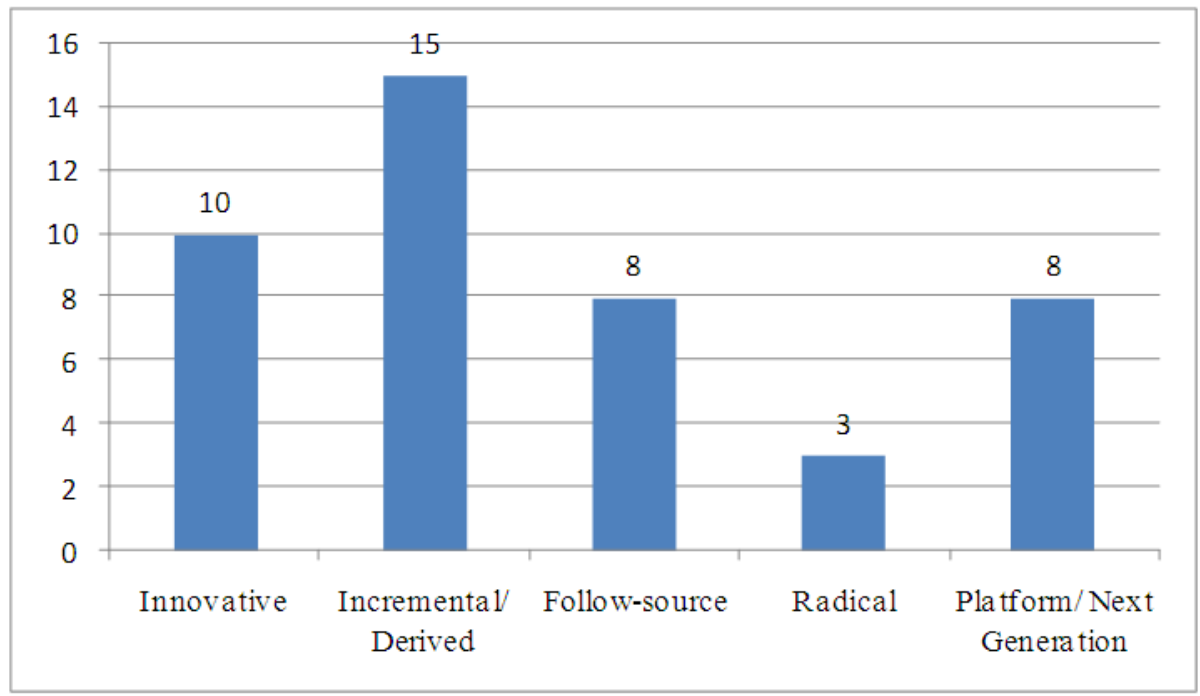

Figure 4. Types of projects.

Haponava and Al-Jibouri (2009) used indicators for the pre project control in the construction industry. So they chose to implement large projects in the Netherlands and found that the most important sub-processes are time management and cost; risk management and project control; definition of customer requirements, start-up project; scope design, stakeholder engagement, planning the pre project, planning of resources and generation of alternative ideas.

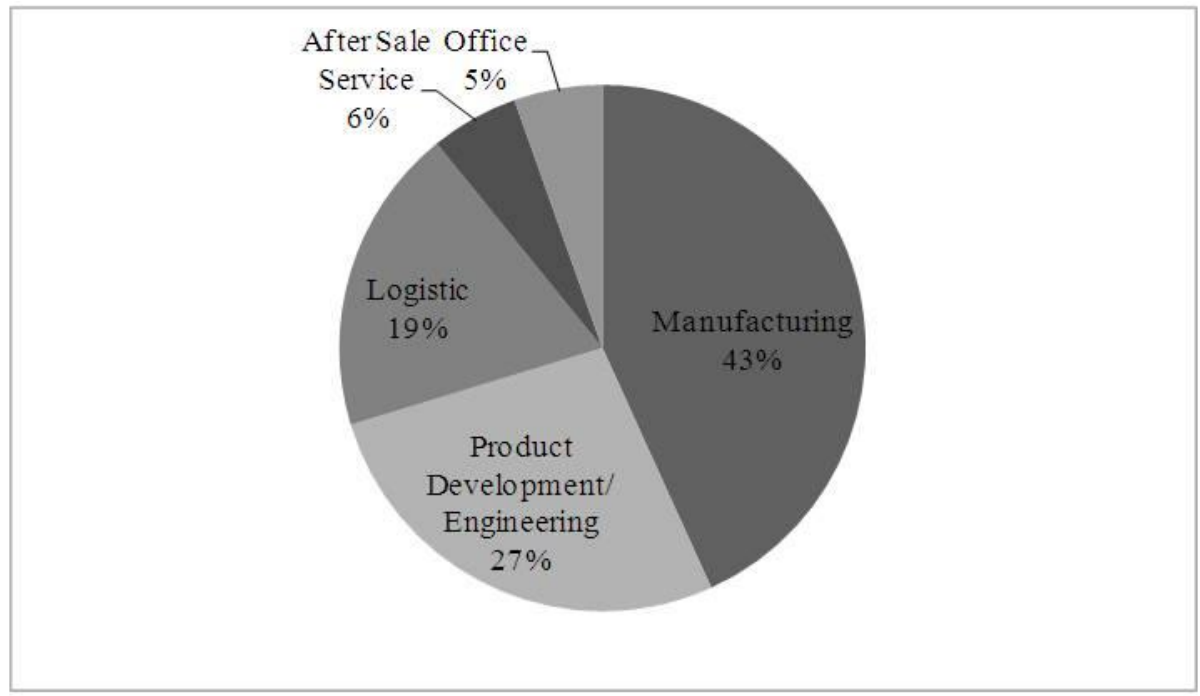

Figure 5. Processes with lean approach. 
To determine if the companies are familiar with lean terminology, they were asked directly if they use this approach. The responses were that $82 \%$ consider themselves lean and $18 \%$ do not. Detailing the question, Figure 5 shows that most of the companies began implementing lean practices to manufacturing (43\%), followed by product development/engineering (27\%) and logistics (19\%).

One of the initial tools for the implementation of a lean approach is value stream mapping. In summary, this process aims to develop a portrait of the current state to visualize some forms of waste and calculate lead time. Afterwards, the improvements are planned in a future map and action plan (Rother \& Shook, 1999; Cheng, Chen, \& Mao, 2010; Badurdeen, Wijekoon, \& Marksberry, 2011; Haponava \& Al-Jibouri, 2009). Chiang (2009) added that information about cost, time of activities, resources, and other important data can be added to the VSM to plan and control the PDP projects. The survey found that $45 \%$ use VSM and 55\% said they do not use this tool.

The standardization of processes is mentioned in two of the 13 principles presented by Morgan and Liker (2006) from Toyota's lean development. The process subsystem calls for "using standardization to reduce variation, create flexibility and predictable results" and the technology subsystem calls for "using powerful tools for standardization and organizational learning". In addition, standardization is a practice for reducing variability, whether of tasks or of arrival of inter-related demand. The first case (variability of task) refers to the differences in the methods and in the duration of the specific tasks found in most product development. The variability of the arrival of related demand refers to the time difference between the deadline set for the arrival of the task at the work station and its actual arrival. This difference is generally caused by the first type of variation and by its capacity restrictions (Morgan \& Liker, 2006).

A standardized development process refers to the standardization of common tasks, the sequence of tasks and the duration of tasks, which will make communication more precise and improve understanding among the functional areas (Koh, Bayraktar, Tatoglu, \& Zaim, 2007; Mottonen, Belt, Harkonen, \& Lin, 2009; Zelbst, Green, Abshire, \& Sower, 2010; Shamsuzzoha, Kyllönen, \& Helo, 2009). In the survey, 95\% of the companies say that they have standardized PDP.

For companies that use a lean approach, the most important factor is to be focused on client satisfaction; for those that do not use the approach, increasing market share and maximizing profits are the most important factors (Meybodi, 2009). Some techniques used to capture the voice of costumer (VOC) are Kano, QFD, Delphi, and Pareto, which various authors maintain are important for categorizing client needs (Zokaei \& Hines, 2007; Ahmed \& Amagoh, 2010; Huang \& Tan, 2007; Boyle \& Scherrer-Rathje, 2009; Chi, Kilduff, \& Gargeya, 2009). In 400 works which found VOC, few apply the tool correctly from the perspective of adding value to the client (Teehan \& Tucker, 2010). In the survey, 68\% of the companies say that they use VOC techniques.

In lean development, the intention is to maintain few suppliers and involve them from the beginning of development and thus establish a long-term partnership. The benefits include decreasing risk, reducing costs and leadtime, as well as joint development and establishment of joint goals (Zelbst et al., 2010; Koh et al., 2007; Cheng et al., 2010; Park, Shin, \& Chang, 2010). Thus, it is strategic to involve the supplier from the beginning of the process, and $95 \%$ of the respondents said that they conduct this practice. According to Brookfield, Liu and Macduffie (2008), co-innovation with suppliers reduces time-to-market by up to $60 \%$. Figure 6 shows that over the past five years, most of the companies evaluated (41\%) followed the practice of reducing the number of suppliers; $32 \%$ have maintained the same number and at $23 \%$ of the companies the quantity increased over the past five years. 


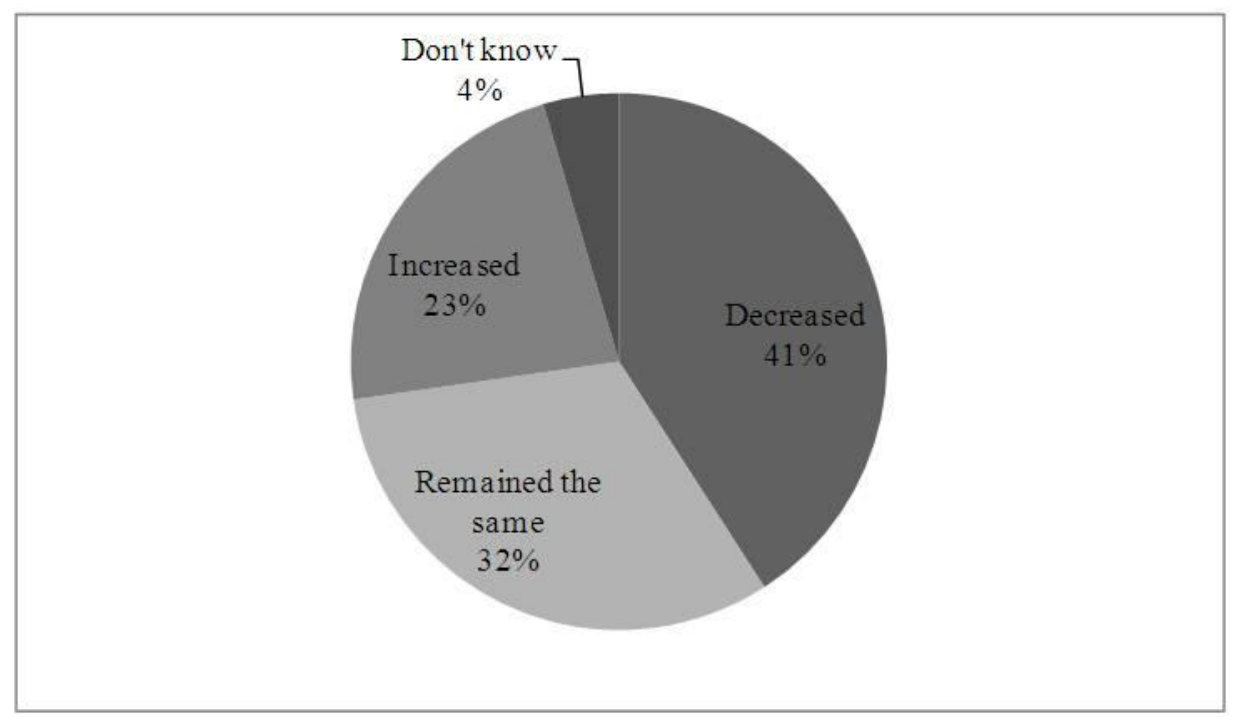

Figure 6. Trend in relation to number of suppliers.

The lean approach affirms that visual management helps control deadlines, performance measurement and does not necessarily require software or high investments. According to Smadi (2009) and Singh, Garg, and Sharma (2009), making problems visible is the first step for applying Kaizen, because only in this way, it is possible to improve and minimize similar problems confronted in the future. It is difficult to develop an understanding of this issue based only on the question in the survey that focused on this subject, and deeper study is needed to indicate if the visual method used functions or not and if those involved are satisfied. Thus, Figure 7 indicated that, as expected, the software MsProject is the most used (49\%), followed by Excel (26\%) and visual chart (11\%). Respondents to this question could mark more than one response.

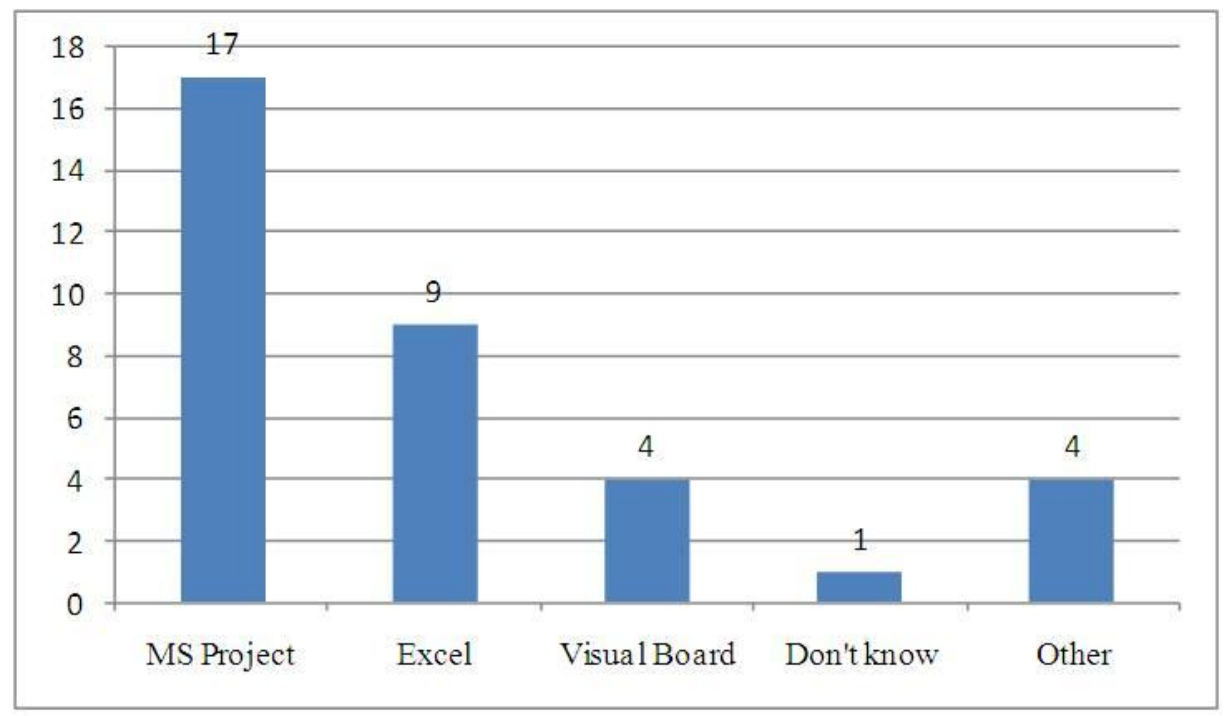

Figure 7. Software used in project management.

Traditionally, development is treated by functional areas, although Rozenfeld et al. (2006) maintained that the roles of those involved in PDP depend on the organizational structure of each project and or company. These authors suggest that those involved include board members, operations managers, those responsible for 
engineering, project management, specialists, partners, the strategic product planning team, the development team, the evaluation team, and the product accompaniment team. In a simple manner, the survey question sought to identify if there is integration between the areas and simultaneous engineering. With this purpose, Rozenfeld et al. (2006), upon developing a reference model for PDP, suggested that nine areas of knowledge participate:

- project management-definition of scope, time frames, human resources, their qualification and the control of activities;

- environment - sustainability, reuse, remanufacturing, recycling, reuse of material, disposal;

- marketing - relationship with the market, such as surveying needs, the insertion and evaluation of products in the market, technological vigilance;

- product engineering-solutions of style, material, functions, structure, and behavior of product, technology integration, etc.;

- process engineering - processes and manufacturing and assembly operations, specification and design of manufacturing resources;

- production - activities that consider the manufacturing of products under development;

- supplies-involves relationships with partners, suppliers, clients on the supply chain and a logistics project to make production viable;

- quality - constant management of the requirements of products, and also involves accompaniment of quality of the business processes of the business resulting from product development and the quality of products in the market after their release;

- costs - definitions of price and target-costs, preparation of a budget, viability study and constant monitoring of this information.

In Figure 8, this paper found that in $86 \%$ of the companies responding, there are at least five areas involved.

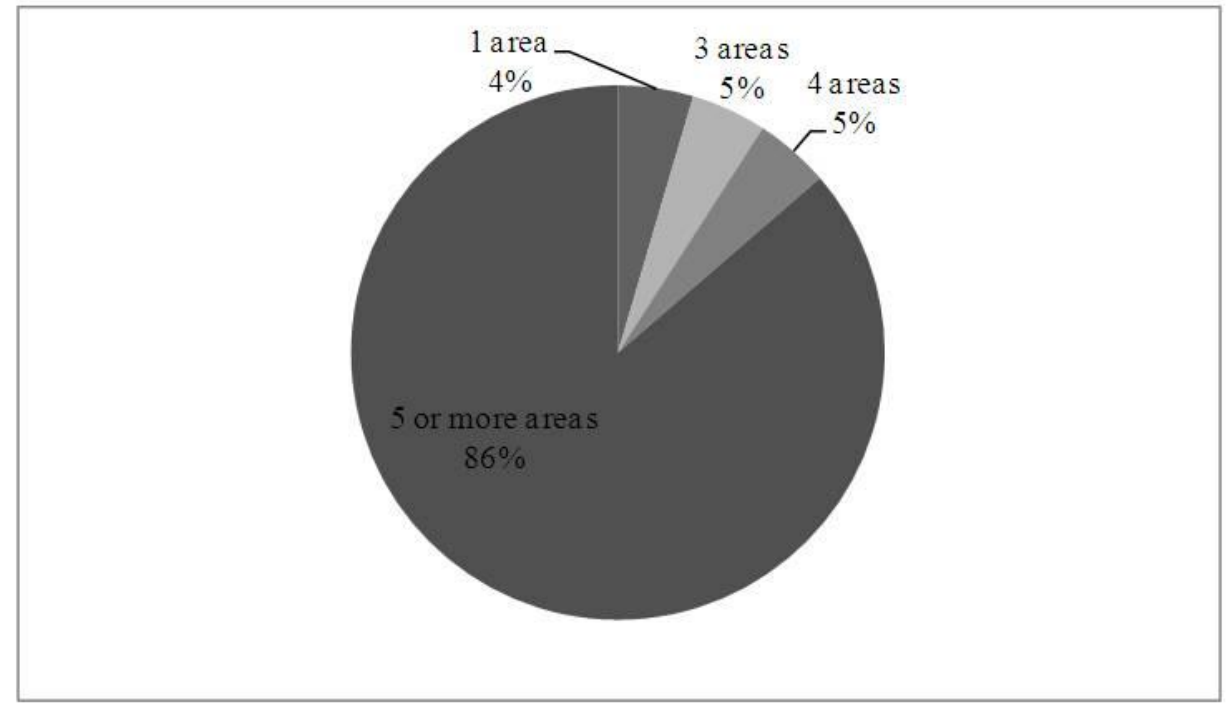

Figure 8. Number of functional areas involved in PDP.

Concurrent engineering is a systematic approach to the integrated and parallel development of the design of a product and the related processes, including manufacturing and support. This approach seeks to have all those involved in PDP consider from the beginning all the project elements from the beginning. In sum, SBCE is developed from concurrent engineering, which emphasizes the development of optional solutions (Rozenfeld 
et al., 2006; Haponava \& Al-Jibouri, 2009).

Through practical experience and the literature, it is understood that SBCE is a junction of all the other lean elements, because its realization requires modularity, integration, technical competence of the staff, the involvement of suppliers at the beginning of the PDP and so on. Thus, this practice was verified by the survey in a very superficial manner, and only the number of alternatives tested was explored (Figure 9).

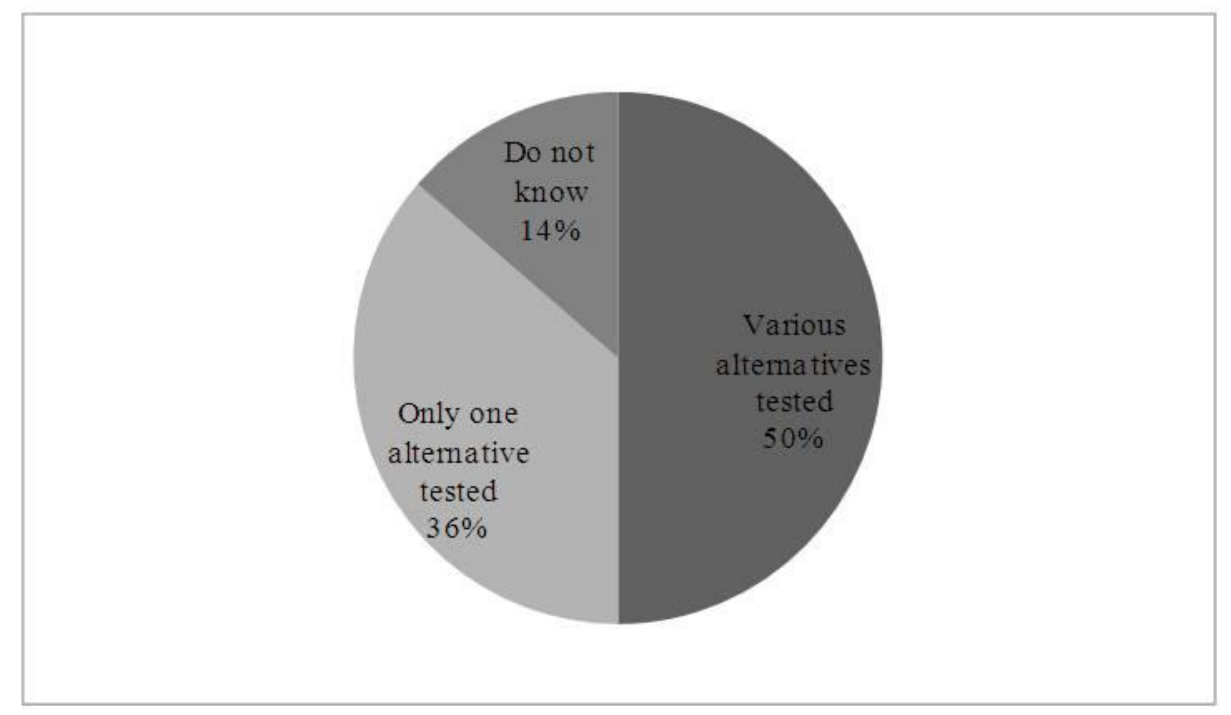

Figure 9. Verification of project alternatives tested.

Considering the first lean principle of Womack and Jones (1996) which specifies value from the client's perspective, within an organization, this involves the practice of valuing the internal client during the flow of information of the PDP. Eighty-two percent of the survey respondents say that they conduct this practice.

Accompanying the project with a certain frequency allows the reactions and changes needed to be conducted on time. In this sense, Japanese culture has the habit of conducting fast daily meetings to establish goals and revise schedules. These meetings, called Kentou, are conducted standing up and last 15 minutes. In Brazil, it was found that $77 \%$ conduct weekly meetings to evaluate project performance (see Figure 10 ). Given that this paper is adapted from the thesis by Dal Forno (2012) in which the survey was detailed and applied later in 12 case studies, the length of an innovative project for the automotive sector varied from 13-19 months. Thus, weekly accompaniment proved to be effective for controlling the scope.

The project library practice refers to the learning process and the habit of recording lessons learned, whether physically or virtually, to facilitate the reuse of knowledge and thus avoid the waste of reinvention. In the survey, there were two similar and complementary questions about this topic. One asked if experiences from past projects are reused. But this knowledge is often not registered, and is lost when employees leave a company. In this way, $95 \%$ of the respondents affirm that in practice there is a reuse of past experiences, nevertheless, registration takes place at $73 \%$ of them.

Conducting virtual simulation through digital modeling (CAD/CAM and other modeling software) is important for predicting errors and interacting with the process, thus reducing costs of physical prototypes and time (Saliba, Zarg, \& Borg, 2010; Grant \& Banomyong, 2010). According to Shamsuzzoha et al. (2009), virtual simulation can take place to integrate supplier and manufacturer, increase the value perceived by the client, and be on target in customized development. Software that allows a client to chose a product (customize) and 
capture value in emotional design is a tool that assists collaboration.

Virtual prototyping aligned to DFM/DFA and CAD/CAPP is useful for evaluating the characteristics of a product, material consumption, geometric form, accuracy, tolerance, and qualitative and quantitative parameters (Bargelis, Kuosmanen, \& Stasiskis, 2009). Among the respondents to the survey, $86 \%$ affirm that they conduct the practice of virtual simulation.

Kaizen signifies a constant search for improvement. This practice is important for determining if there is a concern for continuously improving a process, which was confirmed by the fact that $91 \%$ of the responses were affirmative.

Bilalis, Alvizos, Tsironis, and Wassenhove (2007) mentioned that some indicators of knowledge management are the existence of initiatives of improvement processes, a formal benchmarking process to make comparison with other companies, and the documentation of the performance of past initiatives and of the amount of hours invested in training per employee. When analyzing the latter in the survey, 95\% of the responding companies said they had invested in formal training in the previous year (the survey was issued in 2011).

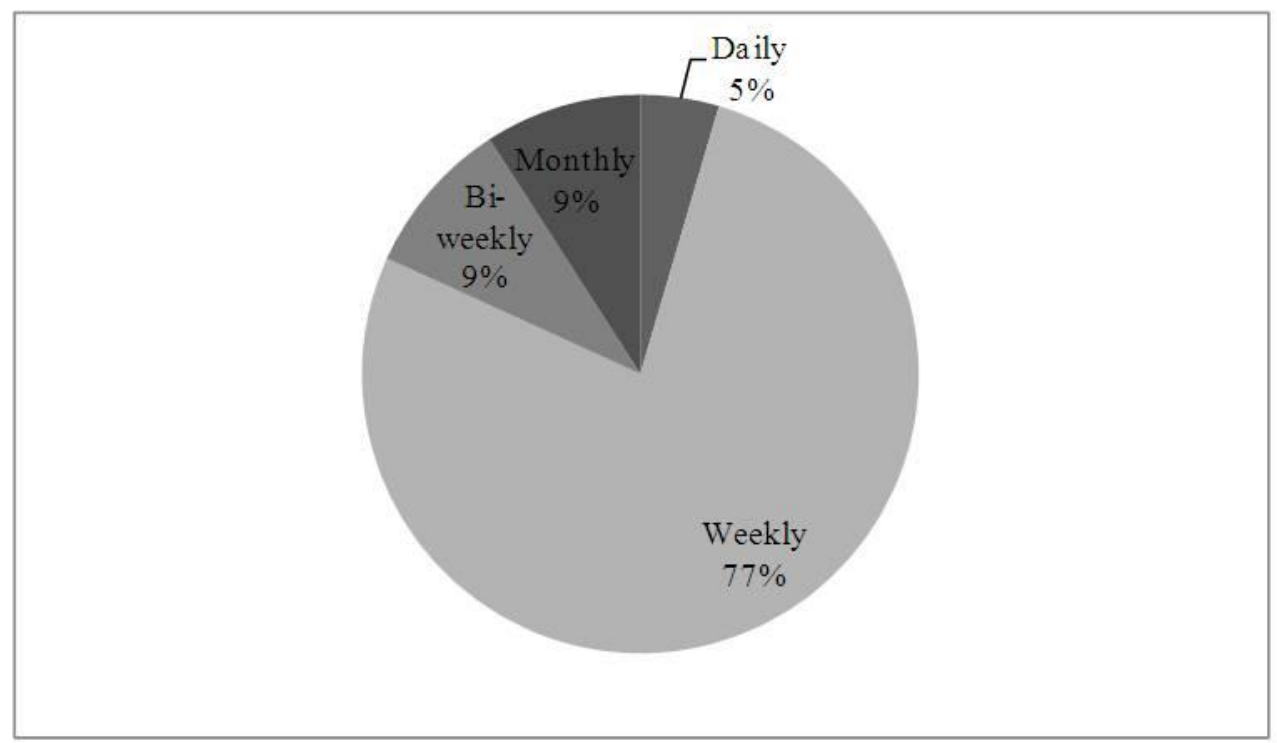

Figure 10. Frequency of reviewing the project.

\section{Statistical Analysis and Evaluation of the Survey}

Cronbach's alpha was used to evaluate the internal coherence of the research tool. According to Corrar, Paulo, and Dias Filho (2009), an analysis of reliability indicates the relations among the individual items on a given scale.

\section{Cronbach's Alpha}

Cronbach's Alpha is a model of internal consistency based on the mean correlations of the items. The reliability is the degree to which a scale produces consistent results among repeated or equivalent measures of a single object or person, revealing the absence of random error (Corrar et al., 2009).

The amount assumed by the Alpha is between 0 and 1 . According to Hair, Anderson, Tatham, and Black (2006), amounts greater than 0.7 are considered as good results, with values up to 0.6 accepted in exploratory research. Malhotra (2005) maintained that the value of the Alpha should be between 0.6 and 1 . This study used 
the amounts suggested by Malhotra (2005). Onoyama (2011) and Schuch (2009) also affirmed that the values should be between 0.6 and 1. Table 3 shows a compilation of the questions conducted in Excel. There are intervals between the numbers of the companies, because the automotive sector is only a portion of the survey conducted in other sectors (Dal Forno, 2012).

The software used to calculate Cronbach's alpha was Statistica 10.0 and SPSS, with the following steps:

(1) Matrix of correlations;

(2) Dispersion graphics;

(3) Average and standard deviation of all the variables;

(4) Histogram;

(5) Box \& Whisper Plot-shows the central trend (mean, interval and quartile) with information to confirm if the distribution of the variables is symmetrical;

(6) Reliability results - total final results of Cronbach's alpha and for each variable.

Table 3

Compilation of the Scores of the Questions.

\begin{tabular}{|c|c|c|c|c|c|c|c|c|c|c|c|c|c|c|c|c|c|c|c|c|}
\hline \multirow{2}{*}{ Company } & \multicolumn{20}{|c|}{ Questions } \\
\hline & 1 & 2 & 3 & 4 & 5 & 6 & 7 & 8 & 9 & 10 & 11 & 12 & 13 & 14 & 15 & 16 & 17 & 18 & 19 & 20 \\
\hline 1 & 5 & 1 & 1 & 5 & 1 & 5 & 2 & 5 & 5 & 1 & 1 & 1 & 5 & 5 & 5 & 2 & 5 & 5 & 5 & 1 \\
\hline 2 & 5 & 1 & 5 & 5 & 0 & 5 & 2 & 5 & 5 & 1 & 5 & 1 & 5 & 5 & 5 & 4 & 5 & 5 & 5 & 1 \\
\hline 3 & 5 & 2 & 5 & 5 & 5 & 5 & 3 & 5 & 5 & 1 & 5 & 5 & 5 & 5 & 5 & 4 & 5 & 5 & 5 & 5 \\
\hline 4 & 5 & 1 & 5 & 5 & 5 & 5 & 4 & 5 & 5 & 5 & 5 & 5 & 5 & 5 & 5 & 4 & 5 & 5 & 5 & 1 \\
\hline 5 & 5 & 3 & 0 & 5 & 5 & 5 & 4 & 5 & 5 & 5 & 5 & 0 & 5 & 5 & 5 & 4 & 5 & 5 & 5 & 5 \\
\hline 6 & 5 & 1 & 1 & 5 & 3 & 5 & 2 & 5 & 5 & 5 & 5 & 5 & 1 & 5 & 1 & 4 & 5 & 1 & 1 & 1 \\
\hline 7 & 1 & 4 & 5 & 5 & 1 & 5 & 4 & 5 & 5 & 5 & 5 & 1 & 5 & 5 & 5 & 4 & 5 & 5 & 5 & 5 \\
\hline 8 & 5 & 0 & 1 & 5 & 3 & 5 & 2 & 5 & 5 & 5 & 5 & 5 & 5 & 1 & 5 & 4 & 5 & 5 & 5 & 1 \\
\hline 9 & 1 & 2 & 1 & 5 & 3 & 5 & 2 & 5 & 5 & 5 & 5 & 5 & 1 & 5 & 5 & 2 & 5 & 5 & 5 & 5 \\
\hline 10 & 5 & 3 & 1 & 5 & 5 & 5 & 4 & 5 & 5 & 5 & 5 & 5 & 5 & 5 & 5 & 4 & 5 & 5 & 5 & 1 \\
\hline 11 & 5 & 2 & 1 & 5 & 5 & 5 & 2 & 5 & 5 & 5 & 4 & 0 & 5 & 5 & 5 & 4 & 1 & 5 & 5 & 1 \\
\hline 12 & 5 & 0 & 1 & 5 & 3 & 5 & 4 & 5 & 5 & 5 & 3 & 1 & 1 & 1 & 5 & 4 & 1 & 5 & 5 & 0 \\
\hline 13 & 1 & 1 & 1 & 5 & 5 & 5 & 2 & 5 & 5 & 5 & 5 & 0 & 5 & 5 & 5 & 3 & 5 & 5 & 5 & 1 \\
\hline 14 & 5 & 1 & 5 & 5 & 3 & 5 & 2 & 5 & 5 & 5 & 5 & 5 & 5 & 5 & 5 & 4 & 5 & 1 & 5 & 5 \\
\hline 15 & 5 & 1 & 1 & 5 & 5 & 5 & 4 & 5 & 5 & 5 & 5 & 5 & 5 & 1 & 5 & 4 & 5 & 5 & 5 & 1 \\
\hline 16 & 5 & 0 & 5 & 5 & 5 & 5 & 2 & 1 & 5 & 5 & 5 & 5 & 5 & 1 & 5 & 4 & 5 & 5 & 5 & 5 \\
\hline 51 & 5 & 0 & 1 & 5 & 1 & 5 & 2 & 1 & 5 & 5 & 5 & 1 & 5 & 5 & 5 & 2 & 5 & 5 & 5 & 5 \\
\hline 53 & 5 & 2 & 5 & 5 & 3 & 5 & 4 & 1 & 5 & 5 & 5 & 5 & 5 & 5 & 5 & 2 & 1 & 5 & 5 & 1 \\
\hline 56 & 1 & 0 & 0 & 5 & 1 & 5 & 3 & 1 & 5 & 5 & 5 & 1 & 5 & 5 & 5 & 4 & 5 & 5 & 5 & 1 \\
\hline 58 & 5 & 3 & 5 & 5 & 5 & 1 & 3 & 0 & 5 & 5 & 3 & 1 & 1 & 1 & 5 & 4 & 1 & 5 & 5 & 1 \\
\hline 59 & 5 & 1 & 5 & 5 & 3 & 5 & 3 & 0 & 5 & 5 & 5 & 5 & 5 & 1 & 5 & 4 & 0 & 5 & 5 & 1 \\
\hline 60 & 5 & 0 & 5 & 2 & 1 & 5 & 3 & 0 & 5 & 5 & 5 & 1 & 5 & 5 & 5 & 3 & 1 & 5 & 5 & 0 \\
\hline
\end{tabular}

Notes. Question 1 (Lean); 2 (Process); 3 (VSM); 4 (ESI); 5 (Supplier quantity); 6 (Standardization); 7 (Physical arrangement); 8 (VOC); 9 (Software); 9 (Software); 10 (Performance indicators); 11 (Departments involved); 12 (SBCE); 13 (Internal customer value); 14 (Lessons learned); 15 (Library project); 16 (Project monitoring); 17 (Virtual simulation); 18 (kaizen); 19 (Training); and 20 (Overtime).

Table 4 shows that the value found for Cronbach's alpha is equal to 0.99 , which, according to M. M. Hill and A. Hill (2008) is considered to be excellent reliability. 
Table 4

Calculation of Cronbach's Alpha for the Survey

\begin{tabular}{|c|c|c|c|c|}
\hline Variable & Mean & Variance & Standard Deviation & Alpha \\
\hline Var1 & 6.07 & 227.55 & 15.08 & 0.99 \\
\hline Var2 & 6.22 & 242.10 & 15.56 & 0.99 \\
\hline Var3 & 6.12 & 233.14 & 15.27 & 0.99 \\
\hline Var4 & 6.10 & 223.18 & 14.94 & 0.99 \\
\hline Var5 & 6.19 & 234.33 & 15.31 & 0.99 \\
\hline Var6 & 6.09 & 222.89 & 14.93 & 0.99 \\
\hline Var7 & 6.16 & 233.39 & 15.28 & 0.99 \\
\hline Var8 & 6.06 & 228.82 & 15.13 & 0.99 \\
\hline Var9 & 6.12 & 222.44 & 14.91 & 0.99 \\
\hline Var10 & 6.17 & 223.40 & 14.95 & 0.99 \\
\hline Var11 & 6.02 & 224.96 & 15.00 & 0.99 \\
\hline Var12 & 6.08 & 230.57 & 15.18 & 0.99 \\
\hline Var13 & 6.09 & 223.15 & 14.94 & 0.99 \\
\hline Var14 & 6.08 & 225.80 & 15.03 & 0.99 \\
\hline Var15 & 6.03 & 222.79 & 14.93 & 0.99 \\
\hline Var16 & 6.12 & 229.17 & 15.14 & 0.99 \\
\hline Var17 & 6.14 & 227.28 & 15.08 & 0.99 \\
\hline Var18 & 6.15 & 222.18 & 14.91 & 0.99 \\
\hline Var19 & 6.14 & 222.98 & 14.93 & 0.99 \\
\hline Var20 & 6.19 & 234.56 & 15.32 & 0.99 \\
\hline
\end{tabular}

Notes. Mean $=6.44 ;$ Standard Deviation $=16.26 ;$ Alpha $=0.99$

\section{Pearson Correlation}

For the statistical analysis and correlation between the questions, the study used Pearson's coefficient of correlation $(\rho)$, also known as the "product-moment correlation coefficient" which measures the degree of correlation (positive or negative) between two variables on the metric scale. If " $\rho=1$ " signifies a perfect positive correlation between the two variables, while " $\rho=-1$ " signifies a negative correlation and when " $\rho=0$ " signifies that the two variables do not depend linearly on each other. Nevertheless, there can be a non-linear dependency. Thus, the result " $\rho=0$ " must be investigated by other means (Runger \& Montgomery, 2010).

Table 5 simplifies the correlation between some questions using Pearson. It can be seen that all had a positive value, that is, the results indicate that the questions are correlated, for example, if the companies use lean, then they have VSM or then the project library and the practice of recording lessons learned are two correlated questions. The calculations were done with the use of an electronic spreadsheet and the software Statistica 10.0.

Table 5

Pearson for the Correlation Between the Questions.

\begin{tabular}{|c|c|c|c|}
\hline Question & & Pearson & Result \\
\hline $5 \mathrm{VSM}$ & 2 Lean & 1 & Positive \\
\hline 21 Training & 20 Kaizen & 1 & Positive \\
\hline $14 \mathrm{SBCE}$ & 19 Virtual Simulation & 1 & Positive \\
\hline 16 Project Library & 17 Lessons Learned & 1 & Positive \\
\hline
\end{tabular}




\section{Conclusions}

For the automotive sector, the strongest practices were ESI, standardization, use of software, project library, continuous improvement of the process, and employee training. In a direct manner, $82 \%$ of the companies from this sector believe that they are lean, although only $45 \%$ conduct VSM and lean practices are implemented in only one process, usually manufacturing. Table 6 presents a summary of the questions that highlights the constructs that the highest number of respondents said that they practiced.

Table 6

Result of the Constructs

\begin{tabular}{|c|c|c|c|}
\hline Construct & Subsystem & Result & $\%$ \\
\hline Project type & Process & Incremental & 34 \\
\hline Use of lean approach & Process & Yes & 82 \\
\hline Processes with lean & Process & 1 process & 36 \\
\hline Year that lean began at the company & Process & 2005 and 2010 & 33 \\
\hline Practice of MFV & Technology & Yes & 45 \\
\hline Early supplier involvement (ESI) & People & Yes & 95 \\
\hline Number of suppliers & Technology & Reduced & 41 \\
\hline Standardization of PDP & Process & Yes & 95 \\
\hline Organizational arrangement & People & Departmental & 45 \\
\hline Voice of consumer & Technology & Yes & 68 \\
\hline Software to accompany schedule & Technology & Yes & 100 \\
\hline PDP indicators & Process & Yes & 86 \\
\hline Areas involved in the PDP & People & Above 5 & 82 \\
\hline SBCE & Technology & Yes & 50 \\
\hline Value of the internal client & People & Yes & 82 \\
\hline Record lessons learned & Process & Yes & 73 \\
\hline Project library/project history & Technology & Yes & 95 \\
\hline Frequency of review of schedule & Process & Weekly & 73 \\
\hline Virtual simulation/digital models & Tool & Yes & 73 \\
\hline Continuous improvement of the process/kaizen & Process & Yes & 91 \\
\hline Employee education/training & People & Yes & 95 \\
\hline
\end{tabular}

It can be concluded that companies are beginning to introduce the lean approach to PDP, although there is still potential to apply many practices and principles that need to take place in a planned and systematic manner. Despite the good rate of return to the survey, the results cannot be generalized. It is important that the academic and business communities continue to develop partnerships to increase competitiveness in the realm of product development, delivering products of value and with an increasingly lower time-to-market.

It is also recognized that companies in Brazil come to consider product development to be a strategic part of their business, altering their profile of follow-source projects for a developing country, with characteristics suitable to the client profile and seeking lean management of processes.

There is global interest in knowing about lean development practices and their impacts on companies. This article highlighted large companies in the Brazilian automotive sector. Conducting the analysis by subsystems helps visualize that the practices related to people are those with the most applications. Table 5 classified them, although all are inter-related, for example continuous improvement through Kaizen is related to the process, they also depends on people. The same is true for other practices. 
The suggestions for future studies are:

- adapting the method to small and medium companies that develop products;

- including an environmental category, with questions that verify practices such as remanufacturing, eco-design, and reverse logistics;

- including a category focused on product-service systems (PSS);

- developing a benchmarking to evaluate if the logistical and administrative processes at companies are lean (purchasing, HR, finance, sales, and maintenance);

- developing a benchmarking organized for the lean application in services-hospitals, banks, restaurants, civil construction, supermarkets, stores, and distribution centers.

\section{References}

Ahmed, S., \& Amagoh, F. (2010). Application of QFD in product development of a glass manufacturing company in Kazakhstan. Benchmarking: An International Journal, 17(2), 195-213.

Badurdeen, F., Wijekoon, K., \& Marksberry, P. (2011). An analytical hierarchy process-based tool to evaluate value systems for lean transformations. Journal of Manufacturing Technology Management, 22(1), 46-65.

Bargelis, A., Kuosmanen, P., \& Stasiskis, A. (2009). Inteligent interface module of process capability among product and process development systems in virtual enviroment. Journal of Mechanical Engineering, 55, 1-9.

Bilalis, N., Alvizos, E., Tsironis, L., \& Wassenhove, L. (2007). Benchmarking the competitiveness of industrial sectors-Application in textiles. International Journal of Productivity and Performance Management, 56(7), 603-622.

Boyle, T. A., \& Scherrer-Rathje, M. (2009). An empirical examination of the best practices to ensure manufacturing flexibility: lean alignment. Journal of Manufacturing Technology Management, 20(3), 348-366.

Brookfield, J., Liu, R., \& Macduffie, J. P. (2008). Taiwan's bicycle industry: A-team battles Chinese competition with innovation and cooperation. Strategy \& Leadership, 36(1), 14-19.

Cheng, H., Chen, M., \& Mao, C. (2010). The evolutionary process and collaboration in supply chains. Industrial Management \& Data Systems, 110(3), 453-474.

Chi, T., Kilduff, P. P. D., \& Gargeya, V. B. (2009). Alignment between business environment characteristics competitive priorities, supply chain structures, and firm business performance. International Journal of Productivity and Performance Management, 58(7), 645-669.

Chiang, T. (2009). The minimum cost PD process planning and control methodology with the consideration of resource time constraints and skill levels. Concurrent Engineering, 17(4), 257-266.

Corrar, L. J., Paulo, E., \& Dias Filho, J. M. (2009). Análise Multivariada para os cursos de Administração, Ciências Contábeis e Economia (FIPECAFI-Fundação Instituto de Pesquisas Contábeis, Atuariais e Financeiras, Atlas, São Paulo, Brazil).

Dal Forno, A. J. (2012). Método de Avaliação via benchmarking do Processo do Desenvolvimento Enxuto de Produtos. Retrieved from http://www.tede.ufsc.br/teses/PEPS5471-T.pdf

Grant, D. B., \& Banomyong, R. (2010). Design of closed-loop supply chain and product recovery management for fast-moving consumer goods. Asia Pacific Journal of Marketing and Logistics, 22(2), 232-246.

Hair, J. E., Anderson, R. E. Tatham, R. L., \& Black, W. C. (2006). Multivariate data analysis (5th ed.). Upper Saddle River: Prentice Hall.

Haponava, T., \& Al-jibouri, S. (2009). Identifying key performance indicators for use in control of pre-project stage process in construction. International Journal of Productivity and Performance Management, 58(2), 160-173.

Hill, M. M., \& Hill, A. (2008). Investigação por Questionário (2nd ed.). Lisboa: Silabo.

Huang, Y. Y., \& Tan, B. (2007). Applications of quality function deployment to apparel design in Taiwan. Journal of Fashion Marketing and Management, 11(2), 215-237.

Koh, S. C. L., Demirbag, M., Bayraktar, E., Tatoglu, E., \& Zaim, S. (2007). The impact of supply chain management practices on performance of SMEs. Industrial Management \& Data Systems, 107(1), 103-124.

Malhotra, N. K. (2005) Introdução à pesquisa de marketing. Porto Alegre: Bookman.

Meybodi, M. Z. (2009). Benchmarking performance measures in traditional and just in time companies. Benchmarking: An International Journal, 16(1), 88-102. 
Morgan, J., \& Liker, J. K. (2006) The toyota product development process: Integrating people, process and technology. New York: Productivity Press.

Mottonen, M., Belt, P., Harkonen, J., \& Lin, B. (2009). Managing requirements in ICT companies. Business Process Management Journal, 15(6), 968-989.

Onoyama, M. M. (2011). Diagnóstico da Gestão do Processo de Desenvolvimento de Produtos em empresas fornecedoras de bens de capital para o setor sucroalcooleiro (Tese em Engenharia de Produção, UFSCAR, São Carlos, Brazil).

Park, J., Shin, K., \& Chang, T. (2010). An integrative framework for supplier relationship management. Industrial Management \& Data Systems, 110(4), 495-515.

Rother, M., \& Shook, J. (1999). Learning to see-Value stream mapping to add value and eliminate MUDA. Cambridge: Lean Enterprise Institute.

Rozenfeld, H., Forcellini, F. A., Amaral, D. C., Toledo, J. C., Silva, S. L., Alliprandini, D. H., \& Scalice, R. K. (2006). Gestão de desenvolvimento de produtos: uma referência para a melhoria do processo. São Paulo: Saraiva.

Runger, G. C., \& Montgomery, D. C. (2010). Applied statistics and probability for engineers (5th ed.). Hardcover: Wiley.

Saliba, M. A., Zarg, A. V., \& Borg, J. C. (2010). A modular, reconfigurable end effector for the plastics industry. Assembly Automation, 30(2), 147-154.

Schuch, C. G. (2009). Proposta de um Modelo para o Planejamento Ágil do Projeto de Produtos. (Programa de Pós Graduação em Engenharia Mecânica. UFSC, Florianópolis, Brazil).

Shamsuzzoha, A., Kyllönen, S., \& Helo, P. (2009). Collaborative customized product development framework. Industrial Management \& Data Systems, 109(5), 718-735.

Sindipeças [Sindicato Nacional da Indústria de Componentes para Veículos Automotores]. (2013). Brazilian autoparts industry performance 2013. Retrieved from http://www.sindipecas.org.br

Singh, B., Garg, S. K., \& Sharma, S. K. (2009). Lean can be a survival strategy during recessionary times. International Journal of Productivity and Performance Management, 58(8), 803-808.

Smadi, S. A. (2009). Kaizen strategy and the drive for competitiveness-Challenges and opportunities. Competitiveness Review: An International Business Journal, 19(3), 203-211.

Teehan, R., \& Tucker, W. (2010). A simplified lean method to capture costumer voice. International Journal of Quality and Service Sciences, 2(2), 175-188.

Womack, J. P., \& Jones, D. T. (1996). Lean thinking. New York: Free Press.

Zelbst, P. J., Green Jr., K. W., Abshire, R. D., \& Sower, V. E. (2010). Relationships among market orientation, JIT, TQM, and agility. Industrial Management \& Data Systems, 110(5), 637-658.

Zokaei, K., \& Hines, P. (2007). Achieving consumer focus in supply chains. International Journal of Physical Distribution \& Logistics Management, 37(3), 223-247. 